\title{
By die dag: Eunice Basson se bedrewe omgang met die brose daaglikse werklikheid
}

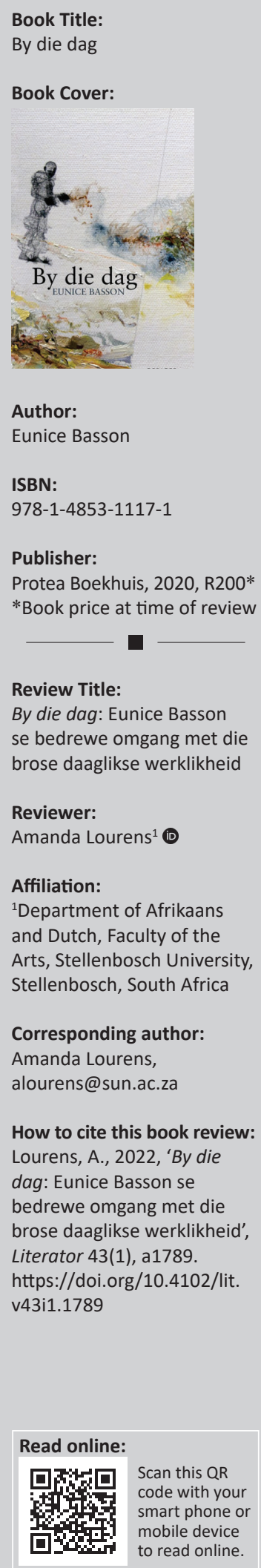

By die dag is die tweede bundel uit die pen van Eunice Basson, kunshistorikus en voormalige universiteitsdosent wat in 2014 met Leiboom debuteer. Hierdie debuut, wat die kortlys vir die Ingrid Jonkerprys haal, word deur Hambidge (2014) as "n behendige bundel wat 'n mens sal onthou om suggestie eerder as direkte segging' bestempel. Du Plooy (2014) sien die bundel ook as een waarin goeie tegniek aanwesig is, en wys terselfdertyd op die konkreetheid en direktheid van die verse. Haar vernaamste beswaar teen Basson se debuut is wel 'dat die sterk beskrywende en soms narratiewe aard verhoed dat die skopus van die gedigte werklik wyer uitsprei en dat 'n groter wêreld in die gedagtes van die leser ontwaak' (Du Plooy 2014). Ten spyte van hierdie beswaar, is haar slotoordeel tog dat sy 'hierdie helder konkrete styl [verkies] bo swaarwigtig-gelade gedigte wat doelbewus alles wil betrek en byna onder hulle eie lading beswyk' (Du Plooy 2014).

Na die lees van Basson se tweede bundel is die leser dan ook dadelik onder die indruk van die digter se vermoë om kort en behendige beskrywende gedigte te skryf. In die tweede bundel slaag sy egter met 'n goeie handvol gedigte daarin om die reikwydte van die verse te vergroot, sodat die groter magte wat die lewe van die enkeling beheer, sonder groot vertoon en op konkrete wyse vir die leser ten tonele gevoer word. Dít doen sy sonder om enigsins aan narratief of beskrywing in te boet.

Die titel van By die dag lê klem op die gedagte van die dag as die basiese eenheid van die menslike lewe (vergelyk ook die motto van Philip Larkin - 'Days are where we live'), maar die gedagte van tydsverloop word slim gesuggereer deur die byhaal van die uitdrukking 'by die dag'. 'By die dag' word normaalweg gebruik om aan te dui dat daar daagliks 'n progressie (of agteruitgang) waargeneem kan word, en die leser verwag onwillekeurig dus ook 'n soort narratief in 'n bepaalde rigting soos die bundel ontvou.

Die gedigte in By die dag sluit in klein portrette van natuurdinge en ook enkelinge in hulle daaglikse lewe, maar dit is veral in laasgenoemde gedigte dat die groter tragiek van menswees uitgebeeld word, en waarin skrynende sosiale onreg blootgelê word. Die ontwikkelende narratief lê myns insiens ook veral op hierdie vlak: Soos die digter met groeiende insig na karakters in die plaaslike maar ook die globale wêreld kyk, word ook die leser se blik verruim om met toenemende deernis, maar ook ontsteltenis, kennis te neem van die pyn wat in die daaglikse bestaan ingebed is.

Die bundel is georganiseer in vier dele sonder titels. Die eerste afdeling handel veral oor die natuur, en die verse in hierdie afdeling vertoon veral uitstekende tegniese vaardighede. Die vloeiende aard van die gedigte val op, en is die produk van die uitstekende hantering van sintaksis en die oordeelkundige gebruik van enjambement.

Verskillende diere word hier aan die orde gestel: daar is heelwat voëls, maar ook 'n werfhond, 'n huislikkewaan en 'n spinnekop. Hierbenewens is dit ook die verhouding tussen die natuur en die mens wat die tematiese aanbod in hierdie afdeling voed. ' $n$ Netjies verwoorde gedig waarin hierdie verhouding sentraal gestel word, is 'Tuinier III' (bl. 24) waarin die karakter se harmonieuse saambestaan met natuurdinge uitgebeeld word - sy vernuf en kennis van argitektuur word ingespan om hom juis in nouer kontak met die natuur te bring:

\footnotetext{
Net genoeg die ruimtes wat hy skep,

maar altyd 'n stoep wat hy beplan of bou

waar hy kan sit en uitkyk op reënvlae

of Hoëveldstorm wat in 'n bloubos
} 
of karee in vurk. Net genoeg is die lappie grond wat hy omspit en bewerk, kompos sif en aanry om laatmiddag pluksels vy en bone vir sy tafel te berei.

\author{
Deesdae in Onderpapegaaiberg \\ stuif nattigheid deur eik en den \\ waar hy hout kan kap, die vuurherd pak \\ en vredig besin oor nog 'n goeie seisoen. \\ Dan skuif hy reg in sy Morris-stoel \\ of by 'n tafel Kaaps en handgemaak, \\ waar hy blaai en naslaan, steeds \\ nuwe wêrelde en ruimtes ontgin.
}

Hierdie gedig is 'n sprekende voorbeeld van Basson se taalgebruik wat nugter en sonder onnodige versiersels, maar terselfdertyd uiters bevredigend is deur onder meer die onverwagse beelde wat dikwels aan die natuur ontleen word (vergelyk 'reënvlae / of Hoëveldstorm wat in 'n bloubos / of karee in vurk').

Die tweede afdeling betrek veral die beeldende kunste, en 'n hele paar gedigte is ekfrasties van aard, byvoorbeeld 'Die ewige kind, 1916' (bl. 38) wat inspeel op 'n skildery deur Irma Stern, asook 'Pontdrif, Limpopo, Junie 1956' (bl. 35) wat verband hou met 'n potloodtekening deur J.H. Pierneef. 'Die ewige kind, 1916 ' is 'n goeie voorbeeld van die manier waarop Basson haar kennis van kunswerke (in hierdie geval ook die ontstaansgeskiedenis van die skildery) inspan om 'n gedig te skep wat resoneer met die groter agtergrond van die oorspronklike werk, maar wat duidelik ook die produk van die digter se eie verbeelding is. In die eerste twee strofes bly die digter redelik na aan die visuele kunswerk, en vereenselwig haar byvoorbeeld in die tweede strofe met die afbeelding van die kind in die skildery wat haar te midde van die 'verrotte uniforms' van WOI bevind. Die slot van hierdie gedig toon egter goed hoe die digter daarin slaag om vérder as die kunswerk te beweeg, en haar eie perspektief op die tragedie van die oorlog te bied:

$$
\begin{aligned}
& {[\ldots]} \\
& \text { Die aarde is immers ruim gevoed } \\
& \text { met ryke murg en been } \\
& \text { van jong en soepel lywe } \\
& \text { wat oordadig lê en verwelk. }
\end{aligned}
$$

Kleur as kunselement word veral beklemtoon, en Basson se groter blik op die wêreld-kunsgeskiedenis blyk uit die naasmekaarstelling van die gedigte 'Blou' (bl. 30), 'Rooi' (bl. 31) en 'Geel' (bl. 32) - elk waarin bepaalde kleurpigmente aan sekere kunstenaars geskakel word. Maar meer betekenisvol nog, verkry sy op hierdie wyse 'n skakeling van die Europese en inheemse kunsvorme.

Dit blyk wel reeds in hierdie afdeling dat die indeling van die bundel in die genoemde vier afdelings nie heeltemal duidelik is nie. Alhoewel dit nie afbreuk doen aan die waardering van die bundel nie, wonder 'n mens wel of die een of ander vorm van aanduider nie dalk waardevol sou wees nie ten einde insig te gee in die digter se siening van die bundel se samehang. (Die rede vir hierdie opmerking is dat ' $n$ hele paar van die gedigte in die tweede afdeling, in hulle fokus op die tragiek van die klein enkeling, ook regstreeks verband hou met die derde afdeling.)

Die pyn van die enkeling, onder wie veral vroue en ander gemarginaliseerdes, asook die temas van die verbygaan van tyd en sterflikheid, kom in die tweede afdeling ter sprake naas die gedigte wat 'n aantoonbare verband met die wêreld van die beeldende kunste het. Een so'n gedig, wat die private pyn uitbeeld van die ouer vrou wat ná dekades steeds oor 'n doodgebore baba rou, is 'Almanak':
[...]
So sit sy dagin, daguit, soms
met haar hande in haar skoot,
maar steeds word dag en datum,
waarvan net sy weet,
jaarliks op die kalender aangestip:
geboorte van 'n baba aan wie sy
slegs die dood kon skenk.

Die realiteit van ouer word - wat daagliks inkrementeel toeneem en ook deel is van die narratief wat die leser van meet af aan vermoed - vind gestalte in verdere gedigte soos 'Meet en pas' bl. 40) en 'Ek neem my ma se hand' (bl. 41), waarin die ouer vrou se verkleinende wêreld uitgebeeld word. In laasgenoemde gedig is die spreker maar te goed bewus van die moeder se sterflikheid wat sy baie nugter en met 'n spatsel ironie verwoord: 'My ma krimp ineen soos die jare / haar gereedkry en nommerpas / vir die laaste reis'.

Die derde afdeling bevat verse wat direk hierby aansluit, soos byvoorbeeld 'Voorslag' (bl. 49) en 'In klein maat' (bl. 50). Eersgenoemde gedig handel oor die tragiek van 'n vrou wie se lewe as sekretaresse hoofsaaklik in diens van'n invloedryke man geslyt is, met die gevolg dat haar eie belange na die marges geskuif is. Laasgenoemde gedig handel weer oor die verskraalde lewens van bejaarde vroue in stede wat elke 'dag in klein maat af[...]sluit' na 'n beskeie inkopietog en geselsies met enkele kennisse, en daarna hulle aande in eensaamheid deurbring. Hierdie nugtere blik op vroulikheid in die latere lewe is vir my een van die besliste sterk punte van die bundel.

Van hier af open die digter die venster op die groter SuidAfrikaanse asook die internasionale toneel, maar fokus steeds op die lot van die enkeling wat nie net 'n slagoffer van 'n steeds heersende patriargale orde is nie, maar ook van 'n onbewoë wêreldorde wat merendeels onbetrokke bly by die lot van die enkeling. Binne die Suid-Afrikaanse konteks gee 'Studie vir 'n voorstedelike herfs, 21 Maart 1960' (bl. 57) 'n nugtere blik op die historiese verdeeldheid en onreg in die land, maar in hierdie geval is die fokus op 'n politiek van die 
huishouding wat die groter samelewingsverhoudings reflekteer. Die digter is bewustelik besig met ' $n$ knap vormlike spel in hierdie gedig wat - sy 16 reëls ten spyt - die opbou van 'n beeld, gevolg deur 'n toepassing, behels:

$$
\begin{aligned}
& \text { Herfs was 'n tyd vir houtkap, } \\
& \text { van stomp tot fynhout stapel } \\
& \text { om later 'n kaggel te pak, } \\
& \text { berge blare vir die komposhoop te hark } \\
& \text { wat muwwerig vrot en vergaan } \\
& \text { tot swartgoud vir Ma se groentetuin. } \\
& \text { Dit was 'n tyd vir lepelkos, vir Pa } \\
& \text { wat swiep-swiep in sy koordferweelbroek } \\
& \text { gangaf stap om biltong in die garage te hang, } \\
& \text { en Miena wat saans die laaste breekware droog, } \\
& \text { en Elias wat die kombuisvloer poets, net ingeval. } \\
& \text { Dit was 'n tyd van die aandklokreël, van snags } \\
& \text { biddend rondsit in 'n agterplaas, van aswit } \\
& \text { kole in konkas aanblaas en 'n laatnagoproep } \\
& \text { oor die trieng-trieng-telefoon, van Miena se Frans - } \\
& \text { oor knuppels, koeëls en bloed in Vereeniging. }
\end{aligned}
$$

Die vierde afdeling fokus dan veral op onregte en sosiale vergrype in verskillende wêrelddele. Die lot van die Siriese vlugtelinge en veral die seuntjie, Alan Kurdi, wat in 2015 saam met sy broer en ma aan die Turkse kus verdrink het, word belig ('By die see', bl. 72); so ook die lot van vroue in
Afghanistan waar kinderbruide hulle vaders se skuld moet betaal ('Papawerbruid, Afghanistan', bl. 7 5). Hierdie laaste afdeling word uiteindelik 'n portret van verskillende vorme van sterwe - sommige selfs nog terwyl die liggaam fisiek voortbestaan.

Die slotgedig bied 'n nugter, maar tog serene beeld op die sterflikheid wat hom vroeër of later aanmeld, en laat die leser met die betekenis dat die lewe 'n daaglikse benadering van die dood is. Die digter-spreker dink haar in 'Niks meer nie' (bl. 80) só in die dood in:

$$
\begin{aligned}
& \text { Wanneer ek soos 'n blaar lig word } \\
& \text { en oor die tuin wegwaai, pluk soos altyd } \\
& \text { dan 'n pot vol krismisrose, pienk en blou, } \\
& \text { vir die voorportaal, oranjegeel } \\
& \text { kappertjies vir geur. } \\
& \text { Vir dit wat was. Niks meer nie. }
\end{aligned}
$$

By die dag is ' $n$ tegnies bedrewe en toeganklike bundel deur 'n digter wat sensitief omgaan met die brose daaglikse werklikheid, en as leser sien 'n mens uit na meer uit Basson se pen.

\section{Literatuurverwysings}

Du Plooy, H., 2014, Resensie: Leiboom, VersIndaba, besigtig 14 Januarie 2021, vanaf https://versindaba.co.za/2014/11/24/resensie-leiboom-eunice-basson/.

Hambidge, J., 2014, Soeke na identiteit in ryk debuut, Netwerk24, besigtig 14 Januarie 2021, vanaf https://www.netwerk24.com/Vermaak/Boeke/Soeke-na-identiteitin-ryk-debuut-20141214. 